Bangladesh J. Plant Taxon. 22(1): 1-8, 2015 (June)

(C) 2015 Bangladesh Association of Plant Taxonomists

\title{
MOLECULAR PHYLOGENETIC ANALYSES OF INTERNAL TRANSCRIBED SPACER (ITS) SEQUENCES OF NUCLEAR RIBOSOMAL DNA INDICATE MONOPHYLY OF THE GENUS PHYTOLACCA L. (PHYTOLACCACEAE)
}

\author{
M. Ajmal Ali ${ }^{1}$, Joongku LeE ${ }^{2}$, Soo-Yong Kim², SAng-Hong Park ${ }^{2,3}$ \\ AND FAHAD M.A. AL-Hemaid \\ Department of Botany and Microbiology, College of Science, King Saud University, \\ Riyadh 11451, Kingdom of Saudi Arabia
}

Keywords: ITS; nrDNA; Phytolaccaceae; Phylogeny.

\begin{abstract}
Relationships within the family Phytolaccaceae sensu lato were examined based on internal transcribed spacer (ITS) sequences of nuclear ribosomal DNA (nrDNA). The study revealed Phytolacca L. as taxonomically the most difficult genus in the family with completely unknown phylogeny. Molecular evidence was used from nrDNA ITS sequences of about $90 \%$ of the species for maximum parsimony analyses, and the molecular phylogenetic analyses defined a monophyletic Phytolacca. This first molecular phylogenetic study of Phytolacca concludes that the relationships among the species within the genus do not show harmony with the generic classification based on morphology. These results set the stage for a more detailed phylogenetic analysis of Phytolacca.
\end{abstract}

\section{Introduction}

The angiosperm family Phytolaccaceae sensu lato comprises a weedy, and polyphyletic genera (APGIII, 2009) of largely tropical and subtropical plants that have been placed, almost without exception, in Centrospermae under either the order Chenopodiales or Caryophyllales (Nowicke, 1969). The genus Phytolacca L. (family Phytolaccaceae) is commonly known as 'pokeweeds' comprises about 20 species (Nowicke, 1969) of perennial herbs, shrubs and trees, nearly cosmopolitan, mostly native to South America, with a few species in Africa and Asia (Shu, 2003). The genus Phytolacca possess alternate, simple leaves, pointed at the end, with entire or crinkled margins; the leaves can be either deciduous or evergreen; the stems are green, pink or red; the flowers are greenish-white to pink, produced in long racemes at the ends of the stems; they develop into globose berries $4-12 \mathrm{~mm}$ in diameter, green at first but dark purple to black after ripening (Nowicke, 1969).

The generic name is derived from the Greek word phyton, meaning plant, and the Latin word lacca, meaning a red dye (Umberto, 2000). Phytolaccatoxin and phytolaccigenin, which are poisonous, are present in many species of the genus Phytolacca. The active principles for analgesic, anti-inflammatory, bactericidal, fungicidal, mitogenic and molluscicide action have been reported from several species of Phytolacca (Hernández et al., 2013). The active principles have also been found in methanolic extracts of fruit of $P$. tetramera Hauman, which is a source of saponins with fungicidal action (Escalante et al., 2002; Santecchia et al., 2002). The African soapberry plant, $P$. dodecandra L'Her., locally called endod, produces a range of triterpenoid

\footnotetext{
${ }^{1}$ Corresponding author. Email: alimohammad@ksu.edu.sa

${ }^{2}$ International Biological Material Research Center, Korea Research Institute of Bioscience and Biotechnology, 125 Gwahak-ro, Yuseong-gu, Daejeon 305-806, South Korea. Email: joongku@kribb.re.kr

${ }^{3}$ Present address: Division of Plant Management, National Institute of Ecology, Choongnam, Secheon-gun, Maseo-myeon, Geumgang-ro, 1210, 325-813, South Korea
} 
saponins possessing very potent and useful biological properties, including antifungal, antiprotozoan, spermicidal and insecticidal activities (Lemma et al., 1979). Because of its fastgrowing nature, $P$. dioica L. is frequently planted as a shade tree in the tropics. Nowicke (1969) reported the use of berries and the young sprouts, and leaves of some species of Phytolacca as an adulterant of red wine and poke salad, respectively.

The generic composition and phylogeny of Phytolaccaceae have long been controversial. The phylogenetic studies have substantially added new results to our knowledge of phylogeny of the family Phytolaccaceae (Brown and Varadarajan, 1985; Downie et al., 1997; Cuenoud et al., 2002; Lee et al., 2013). Nowicke (1969) referred Phytolacca as the most difficult genus in the family Phytolaccaceae sensu lato, and classified under three subgenera and six sections (Table 1). However, comprehensive information on phylogeny of the genus Phytolacca is lacking.

Table 1. Infrageneric classification of the genus Phytolacca L. by Nowicke (1969). Taxa included in the present study are marked with asterisk.

\begin{tabular}{|c|c|c|}
\hline Subgenus & Section & Species \\
\hline \multirow[t]{2}{*}{ Pircunia } & Pircunia & $\begin{array}{l}\text { *Phytolacca acinosa Roxb. } \\
\text { *P. heptandra Retz. }\end{array}$ \\
\hline & Pircunioides & *P. dodecandra L'Her. \\
\hline \multirow[t]{2}{*}{ Pircuniopsis } & Pircuniophorum & $\begin{array}{l}\text { *P. sanguinea } \mathrm{H} \text {. Walter } \\
{ }^{*} \text { P. rugosa } \mathrm{Br} \text {. \& Bouche } \\
\text { P. chilensis (Miers ex Moq.) H. Walter }\end{array}$ \\
\hline & Pircuniopsis & $\begin{array}{l}\text { *P. tetramera Hauman } \\
* P \text {. dioica L. } \\
\text { *P. weberbaueri H. Walter }\end{array}$ \\
\hline \multirow[t]{2}{*}{ Phytolacca } & Phytolacca & $\begin{array}{l}\text { *P. icosandra L. } \\
\text { *P. octandra L. } \\
\text { *P. thyrsiflora Fenzl ex J.A. Schmidt } \\
\text { *P. heterotepala H. Walter } \\
\text { *P. meziana H. Walter } \\
\text { *P. rivinoides Kunth \& Bouchk } \\
\text { *P. purpurascens A. Br. \& Bouche } \\
\text { *P. brachystachys Moq. } \\
\text { *P. bogotensis H.B.K. } \\
\text { *P. americana L. }\end{array}$ \\
\hline & Phytolaccoides & P. pruinosa Fenzl. \\
\hline
\end{tabular}

During the last two decades, the internal transcribed spacers (ITS) sequences of nuclear ribosomal DNA (nrDNA) have gained wide attention, not only because of its efficacy in understanding phylogeny of the plants at lower taxonomic level, but also to be considered as the most conserved markers, because, even after facing criticism of its utility, this marker stands parallel to the smartest genes available for the molecular phylogeny and plant DNA barcoding (Ali et al., 2013, 2014). The nrDNA ITS sequences have, therefore, provided a useful source of phylogenetic information in many genera and families of flowering as well as non-flowering plants (Ali et al., 2015), including Phytolaccaceae (Lee et al., 2013). Hence, as such the nrDNA ITS are appropriate to analyze for the genus Phytolacca too. 


\section{Materials and Methods}

Taxa examined

Twenty taxa representing five sections (i.e. Phytolacca, Pircunia, Pircunioides, Pircuniophorum and Pircuniopsis) under three subgenera (i.e. Phytolacca, Pircunia and Pircuniopsis) of Phytolacca and two outgroup taxa (namely Petiveria alliacea F. Muell. and Monococcus echinophorus L.) were sampled from specimens deposited in the Herbarium of University of California (UC), Berkeley, USA (Table 2). Petiveria alliacea and M. echinophorus were chosen as outgroup taxa because of their close affinity to Phytolacca (Lee et al., 2013).

Table 2. Accessions of the genus Phytolacca L. examined in this study.

\begin{tabular}{|c|c|c|c|}
\hline Taxon & Voucher & Locality & $\begin{array}{l}\text { GenBank } \\
\text { Acc. No. }\end{array}$ \\
\hline \multicolumn{4}{|l|}{ Ingroup } \\
\hline Phytolacca acinosa & M.T. Yu et al. s.n. & Tibet & EU239681 \\
\hline P. americana & D.W. Taylor 7922 (UC/JEPS) & California, USA & JX232573 \\
\hline P. bogotensis & H.L. Mason 23712 (UC) & Colombia, South America & KM491868 \\
\hline P. brachystachys & F.R. Fosberg 9004 (UC) & Hawaiian Island, USA & KM491869 \\
\hline P. dioica & Marquez et al. 38645 (UC) & Mexico, North America & JX232571 \\
\hline P. dodecandra & R.E.S. Tanner 572 (UC) & Tanganyika, Africa & KM491870 \\
\hline P. heptandra & L.C.C. Libeoberg 5830 (UC) & South Africa & KM491871 \\
\hline P. heterotepala & Sally Pugh s.n. (UC) & California, USA & KM491872 \\
\hline P. icosandra & J.H. Beaman 2749 (UC) & Mexico, North America & JX232570 \\
\hline P. meziana & Edward 89055 (UC) & Mexico, North America & KM491873 \\
\hline P. octandra & G.J. Martin 468 (UC) & Oaxaca, Mexico, North America & KM491874 \\
\hline P. purpurascens & W.H. Wagher 5027 (UC) & Hawaiian Island, USA & KM491875 \\
\hline P. rivinoides & J. Nowicke 874 (UC) & Panama, Central America & KM491876 \\
\hline P. rugosa & A. Weston 5981 (UC) & Costa Rica, Central America & KM491877 \\
\hline P. sanguinea & J. H. Langenneim 3576 (UC) & Colombia, South America & KM491878 \\
\hline P. tetramera & N. Tur 1329 (UC) & Argentina, South America & KM491879 \\
\hline P. thyrsiflora & C. Chung 4248 (UC) & California, USA & KM491880 \\
\hline P. weberbaueri & C.H. Dodson 6481 (UC) & Ecuador, South America & KM491881 \\
\hline \multicolumn{4}{|l|}{ Outgroup } \\
\hline $\begin{array}{l}\text { Monococcus } \\
\text { echinophorus }\end{array}$ & Franch 1130 (UC) & New Caledonia & JX232579 \\
\hline Petiveria alliacea & C.A. Purpus 2272 (UC) & Mexico, North America & JX232580 \\
\hline
\end{tabular}

Molecular methods

Total genomic DNA was extracted by use of the DNeasy Plant Mini Kit from Qiagen (Valencia, CA, USA). The nrDNA ITS regions were amplified using the primers ITS1 and ITS4 (White et al., 1990). The DNA amplification for 35 cycles was carried out through PCR. Initial denaturation was carried out at $94^{\circ} \mathrm{C}$ for $5 \mathrm{~min}$, followed by denaturation at $94^{\circ} \mathrm{C}$ for $1 \mathrm{~min}$, annealing at $48^{\circ} \mathrm{C}$ for $1 \mathrm{~min}$, extension at $72^{\circ} \mathrm{C}$ for $1 \mathrm{~min}$, and the final extension at $72^{\circ} \mathrm{C}$ for 5 min. The PCR products were purified using SolGent PCR Purification kit-Ultra (SolGent, Daejeon, South Korea). For sequencing, the Big Dye Terminator chemistry (ABI) and an ABI 3100 Avant capillary sequencer were used. All sequences were BLAST-searched in GenBank. 
Sequence alignments and phylogenetic analyses

Sequences were edited using the ABI Sequence Navigator (Perkin-Elmer/Applied Biosystems, USA). Sequence alignment was performed using Clustal X version 1.81 (Thompson et al., 1997), and subsequently adjusted manually using BioEdit (Hall, 1999). Information on sequence alignment can be made available from the corresponding author. Data were exported as a nexus file and subsequently analyzed using Maximum Parsimony (MP) in PAUP* 4.0b10 (Swofford, 2002). The MP analysis was performed with the following settings: heuristic search algorithms with tree bisection reconnecting (TBR) branch swapping, MULPARS in effect, all characters equally weighted, gap treated as missing characters, zero-length branches collapsed, random addition sequence set to 1000 replicates, and branch swapping limited to $10,000,000$ rearrangements per replicate. When maximum parsimony trees were saved, a strict consensus tree was constructed. Bootstrap analysis was performed using 1000 replicates, with the random addition sequence set to 10 , and branch swapping limited to $10,000,000$ rearrangements per replicate.

\section{Results and Discussion}

Sequence characteristics

The combined length of the entire ITS region (ITS1, 5.8S and ITS2) from taxa analyzed in the present study ranged from 609-631 nucleotides (nt). The length of the ITS1 region and GC contents ranged from $220-232 \mathrm{nt}$ and $56 \%-63 \%$, the $5.8 \mathrm{~S}$ gene was $166 \mathrm{nt}$ long, the length of the ITS2 region and the GC content ranged from $221-235$ nt and $55 \%-63 \%$, respectively. Data matrix has a total number of $654 \mathrm{nt}$ characters of which $423 \mathrm{nt}$ characters were constant, $88 \mathrm{nt}$ characters were variable but parsimony-uninformative, and $143 \mathrm{nt}$ characters were parsimony-informative.

\section{Phylogenetic analyses}

The parsimony analysis of the entire ITS region resulted a total number of four maximally parsimonious trees (MPTs) with a total length of 252 steps, a consistency index (CI) of 0.7110 , a homoplasy index (HI) of 0.2890 , rescaled consistency index (RC) of 0.5361 and a retention index (RI) of 0.7540 (Fig. 1).

The rooted bootstrap strict consensus parsimony tree (Fig. 1) revealed that the monophyly of Phytolacca species is supported with $100 \%$ parsimony bootstrap support (BS). All trees resulted from the analysis of ITS sequences resolve three major clades (Clades I-III, Fig. 1). The Clade I consists of $P$. heptandra, the Clade II (96\% BS) consists of members of subgenus Pircuniopsis (i.e. P. dioica, P. tetramera and P. weberbaueri), and the Clade III (56\% BS) consists of $[P$. americana $+(P$. dodecandra $-P$. acinosa $-P$. purpurascens $)+(P$. rivinoides $-\{P$. rugosa $P$. thyrsiflora $+P$. icosandra $-P$. brachystachys $-P$. heterotepala $+P$. octandra - P. meziana $P$. sanguinea - $P$. bogotensis $\}$ )].

The generic composition of Phytolacca has long been controversial principally due to common occurrence of intraspecific variability and hybridization (Fassett and Sauer, 1950; Sauer, 1951). Walter (1909) placed 26 species of Phytolacca into three subgenera based on the degree of connation of the carpels: free, connate at the base with the apices free, or completely united carpels. The subgenus Pircunia (Moq.) H. Walter contains P. heptandra Retz., P. esculenta van Houtte, P. acinosa Roxb., P. latbenia (Buch.-Ham.) H. Waiter and P. cyclopetala H. Walter under the Sect. Pircuniastrum Moq. characterized by hermaphroditic flowers, and P. dodecandra, P. goudotii Briq. and P. nutans H. Walter under the Sect. Pircunioides H. Walter characterized by dioecious plants. The subgenus Pircuniopsis H. Walter characterized by carpels connate at the base with the apices free, contains a hermaphroditic group, the Sect. Pircuniophorum H. Walter, 
with three species, P. chilensis (Miers ex Moq.) H. Walter, P. rugosa Br. \& Bouche and $P$. sanguinea $\mathrm{H}$. Walter, and the Sect. Pseudolacca Moq., with two dioecious species, P. dioica and $P$. weberbaueri $\mathrm{H}$. Walter. The subgenus Euphytolacca Moq., the largest group characterized by carpels completely united contains a very large hermaphroditic flower, has the Sect. Phytolaccastrum H. Walter with P. americana L., P. australis Phil., P. brachystachys Moq., P. heterotepala H. Walter, P. icosandra L., $P$. meziana H. Walter, $P$. micrantha H. Walter, $P$. octandra L., P. polyandra Batalin, P. purpurascens A. Br. \& Bouche, P. rivinoides Kunth \& Bouchk and $P$. thyrsiflora Fenzl ex J.A. Schmidt, and a monotypic dioecious Sect. Phytolaccoides H. Walter containing P. pruinosa Fenzl. Later on Heimerl (1934) noted approximately 35 species of Phytolacca; however, Nowicke (1969) did not consider the names assigned to hybrid origin. Nowicke (1969) recognized a total of 20 species in the genus Phytolacca and classified them into

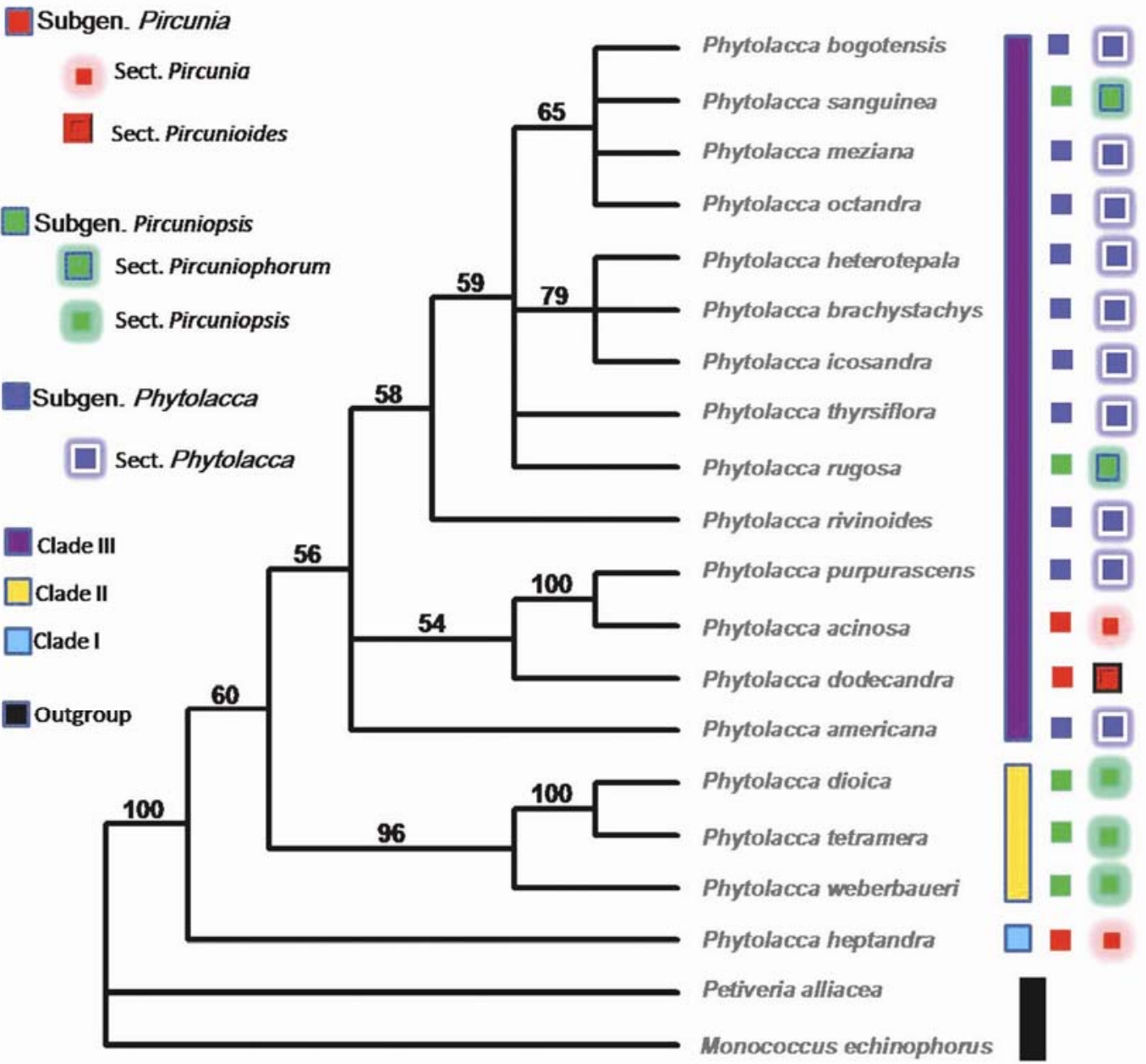

Fig. 1. The bootstrap strict consensus of four maximally parsimonious trees of Phytolacca L. species based on the ITS sequence with gaps being treated as missing data $(252$ steps, $\mathrm{CI}=0.71, \mathrm{HI}=0.28, \mathrm{RC}=0.53$ and $\mathrm{RI}=0.75)$. Bootstrap values greater than $50 \%$ in 1000 replicates are shown above lines. 
three subgenera, i.e. Pircunia (carpels completely free), Pircuniopsis (carpels more or less united) and Phytolacca (carpels completely united, the styles more or less connivent). Based on characteristic of flowers, Nowicke (1969) divided the subgenus Pircunia into two sections: Pircunia (P. acinosa and P. heptandra) and Pircunioides (P. dodecandra); Pircuniopsis into two sections: Pircuniophorum (P. chilensis, P. rugosa and P. sanguinea) and Pircuniopsis (P. dioica, $P$. tetramera and P. weberbaueri); and Phytolacca into two sections: Phytolacca (P. americana, P. bogotensis H.B.K., P. brachystachys, P. heterotepala, P. icosandra, P. meziana, P. octandra, $P$. purpurascens, $P$. rivinoides and $P$. thyrsiflora) and Phytolaccoides (P. pruinosa).

In our study, the Clade I, which occupies independently at the basal position in MPT, consists of only P. heptandra. Phytolacca heptandra was treated along with $P$. esculenta, P. acinosa, $P$. latbenia and P. cyclopetala under the subgenus Pircunia, Sect. Pircuniastrum (Walter, 1909). Nowicke (1969) also treated P. heptandra along with P. acinosa under the subgenus Pircunia Sect. Pircunia.

The Clade II (96\% BS) consists of P. dioica, P. tetramera and P. weberbaueri. In Walter's (1909) classification P. dioica, P. tetramera and $P$. weberbaueri are under the subgenus Pircuniopsis, Sect. Pseudolacca. Nowicke (1969) also treated these under the subgenus Pircuniopsis Sect. Pircuniopsis.

The Clade III (56\% BS) consists of members mainly belonging to subgenus Phytolacca Sect. Phytolacca (i.e. P. americana, P. brachystachys, P. bogotensis, P. heterotepala, P. icosandra, P. meziana, $P$. octandra, $P$. purpurascens, $P$. rivinoides and $P$. thyrsiflora, $)$, and those treated under subgenus Pircunia Sect. Pircunioides (P. dodecandra), subgenus Pircunia Sect. Pircunia (P. acinosa) and subgenus Pircuniopsis Sect. Pircuniopsis ( $P$. sanguinea and $P$. rugosa) of Nowicke (1969). In the Walter (1909) treatment, P. americana, P. brachystachys, P. heterotepala, $P$. icosandra, $P$. meziana, $P$. octandra, $P$. purpurascens, $P$. rivinoides and $P$. thyrsiflora, were treated under subgenus Euphytolacca Sect. Phytolaccastrum, while $P$. dodecandra under subgenus Pircunia Sect. Pircunioides, P. acinosa under subgenus Pircunia Sect. Pircuniastrum, and P. sanguinea and $P$. rugosa under subgenus Pircuniopsis Sect. Pircuniophorum.

The Clade III further bifurcates into four subclade, namely (IIIa) P. americana; (IIIb) $P$. acinosa, $P$. dodecandra and $P$. purpurascens; (IIIc) P. rivinoides; and (IVd) P. bogotensis, $P$. brachystachys, $P$. heterotepala, $P$. icosandra, $P$. meziana, $P$. octandra, $P$. rugosa, $P$. sanguine and $P$. thyrsiflora. Under the subclade IVd, $P$. bogotensis, $P$. meziana \& $P$. sanguinea, and $P$. brachystachys, $P$. heterotepala \& $P$. icosandra, are grouped together, and these two groups show polytomic relationships with $P$. rugosa and $P$. thyrsiflora.

It is interesting to note that $P$. rugosa and $P$. sanguinea, [subgenus Pircuniopsis Sect. Pircuniopsis of Nowicke (1969) and subgenus Pircuniopsis Sect. Pircuniophorum of Walter (1909)] are nested within the Clade III, while the other members, namely P. dioica, P. tetramera and P. weberbaueri [subgenus Pircuniopsis Sect. Pseudolacca of Walter (1909) and subgenus Pircuniopsis Sect. Pircuniopsis of Nowicke (1969)] form a separate Clade II with strong bootstrap support $(96 \% \mathrm{BS})$.

Phytolacca acinosa [subgenus Pircunia Sect. Pircuniastrum of Walter (1909) and subgenus Pircunia Sect. Pircunia of Nowicke (1969)] and P. dodecandra [subgenus Pircunia Sect. Pircunioides of Walter (1909) and subgenus Pircunia Sect. Pircunioides of Nowicke (1969)] grouped together with $P$. purpurascens (54\% BS), while P. heptandra [Subgen. Pircunia Sect. Pircuniastrum of Walter (1909) and subgenus Pircunia Sect. Pircunia of Nowicke (1969)] occupies basal most position in the MPTs as a separate clade.

In conclusion, this is the first inclusive study using molecular nrDNA ITS sequences to estimate phylogenetic relationships of Phytolacca. It is clearly evident that the phylogenetic trees 
resulting from the analysis of nrDNA ITS sequences are strongly supported as a monophyletic group $(100 \% \mathrm{BS})$. However, the relationships among the species within the genus do not show harmony with the previous generic classification based on morphology. In the present analysis, a total number of 143 out of $654(21 \%)$ sites of sequence data set were phylogenetically informative, so further sampling of additional taxon and addition of more regions are needed for the robust phylogeny of the genus Phytolacca. We herein based on the present analysis hypothesize that the intraspecific classification of Phytolacca should be recircumscribed into subgenus Phytolacca ( $P$. acinosa, P. americana, P. bogotensis, $P$. brachystachys, $P$. dodecandra, $P$. heterotepala, $P$. icosandra, $P$. meziana, $P$. octandra, $P$. purpurascens, $P$. rivinoides, $P$. rugosa, $P$. sanguinea and $P$. thyrsiflora), subgenus Pircuniopsis ( $P$. dioica, $P$. tetramera and $P$. weberbaueri), and $P$. heptandra should be treated under an independent subgenus. This treatment, as a hypothesis, however, needs testing and further data would help to clarify their true intraspecific affinities.

\section{Acknowledgements}

The first and second authors provided an equal contribution to this paper. Grant support (\#2011-00402) from the Ministry of Education, Science and Technology, Government of South Korea to the second author is thankfully acknowledged. Authors thank to the curators of The University and Jepson Herbarium (UC), University of California, Berkeley, USA for providing plant materials for the study. The first and last authors acknowledge research supported by the King Saud University, Deanship of Scientific Research, College of Science, Research Center.

\section{References}

Ali, M.A, Al-Hemaid, F.M., Choudhary, R.K., Lee, J., Kim, S.Y. and Rub, M.A. 2013. Status of Reseda pentagyna Abdallah \& A.G. Miller (Resedaceae) inferred from combined nuclear ribosomal and chloroplast sequence data. Bangladesh J. Plant Taxon. 20(2): 233-238.

Ali, M.A., Gábor, G., Norbert, H., Balázs, K., Al-Hemaid, F.M.A., Pandey, A.K. and Lee, J. 2014. The changing epitome of species identification - DNA barcoding. Saudi J. Biol. Sci. 21(3): 204-231.

Ali, M.A., Pandey, A.K., Al-Hemaid, F.M.A., Lee, J., Pandit, B., Kim, S.Y., Gyulai, G. and Rahman, M.O. 2015. Nuclear Sequences in Plant Phylogenetics. In: Ali, M.A., Gábor, G. and Al-Hemaid, F.M.A. (Eds), Plant DNA Barcoding and Phylogenetics. Lambert Academic Publishing, Germany, pp. 37-52.

APG III 2009. An update of the Angiosperm Phylogeny Group classification for the orders and families of flowering plants: APG III. Bot. J. Linn. Soc. 161:105-121.

Brown, G.K. and Varadarajan, G.S. 1985. Studies in Caryophyllales I: Re-evaluation of classification of Phytolaccaceae s.l. Syst. Bot. 10: 49-63.

Cuenoud, P., Savolainen, V., Chatrou, L.W., Powell, M., Grayer, R.J. and Chase, M.W. 2002. Molecular phylogenetics of Caryophyllales based on nuclear $18 \mathrm{~S}$ rDNA and plastid $r b c \mathrm{~L}$, atpB, and matK DNA sequences. Am. J. Bot. 89: 132-144.

Downie, S., Katz-Downie, D. and Cho, K. 1997. Relationships in the Caryophyllales as suggested by phylogenetic analyses of partial chloroplast DNA ORF2280 homolog sequences. Am. J. Bot. 84: 253273.

Escalante, A.M., Santecchia, C.B., López, S.N., Gattuso, M.A., Gutiérrez, A., Delle Monache, F., González Sierra, M. and Zacchino, S.A. 2002. Isolation of antifungal saponins from Phytolacca tetramera, an Argentinean species in critic risk. J. Ethnopharmacol. 1: 29-34.

Fassett, N. and Sauer, J. 1950. Studies of variation in the weed genus Phytolacca. 1. Hybridizing species in northeastern Colombia. Evolution 4: 332-339.

Hall, T.A. 1999. BioEdit: a user-friendly biological sequence alignment editor and analysis program for Windows 95/98/NT. Nucleic Acids Symp. Ser. 41: 95-98. 
Heimerl, A. 1934. Phytolaccaceae. In: Engler, A. and Prantl, K. (Eds), Die naturlichen Pflanzenfamilien. 2nd edition. Leipzig, Wilhelm Engelmann, 4: 135-164.

Hernández, M., Murace, M., Ringuelet, J., Petri, I., Gallo, D. and Arambarri, A. 2013. Effect of aqueous and alcohol extracts of Phytolacca tetramera (Phytolaccaceae) leaves on Colletotrichum gloeosporioides (Ascomycota). Bol. Soc. Argent. Bot. 48(2): 201-209.

Lee, J., Kim, S.Y., Park, S.H. and Ali, M.A. 2013. Molecular phylogenetic relationships among members of the family Phytolaccaceae sensu lato inferred from internal transcribed spacer sequences of nuclear ribosomal DNA. Genet. Mol. Res. 12(4): 4515-4525.

Lemma, A., Heyneman, D. and Kloos, H. (Eds). 1979. Studies on the molluscicidal and other properties of the endod plant, Phytolacca dodecandra, with special emphasis on the epidemiology of Schistosomiasis in Ethiopia and the possibility of localized control using endod as a molluscicide on a community selfhelp basis. Addis Ababa University, Ethiopia; University of California, San Francisco.

Nowicke, J.W. 1969. Palynotaxonomic study of the Phytolaccaceae. Ann. Miss. Bot. Gard. 55: 94-363.

Santecchia, C., Escalante, A., Gattuso, M., Zacchino, M., Gutierrez Ravelo, A., Delle Monache, F. and Gonzalez Sierra, F. 2002. Phytolacca tetrámera, una fuente de saponinas triterpenoides. Revista Lat. Am. Quim. 28: 246-247.

Sauer, J. 1951. Studies of variation in the weed genus Phytolacca. II. Latitudinally adapted variants within a North American species. Evolution 5: 273-279.

Shu, S.L. 2003. Phytolacca. In: Wu, Z.Y., Raven, P.H. and Hong, D.Y. (Eds), Flora of China. Vol. 5. Science Press, Beijing and Missouri Botanical Garden Press, St Louis, pp. 435-436.

Swofford, D.L. 2002. PAUP: Phylogenetic Analysis using Maximum Parsimony (and Other Methods). Version 4.0b 10. Sinauer, Sunderland, Massachusetts.

Thompson, J.D., Gibson, T.J., Plewniak, F., Jeanmougin, F. and Higgins, D.G. 1997. The Clustal X windows interface: Flexible strategies for multiple sequence alignment aided by quality analysis tools. Nucleic Acids Res. 24: 4876-4882.

Umberto, Q. 2000. CRC World Dictionary of Plant Names: Common Names, Scientific Names, Eponyms, Synonyms, and Etymology. CRC press Taylor \& Francis, New York, pp. 1-2065.

Walter, H. 1909. Phytolaccaceae. In: Enler, A. Pflanzenr. IV 83 (Heft 39): 1-154.

White, T.J., Bruns, T., Lee, S. and Taylor, J. 1990. Amplification and direct sequencing of fungal ribosomal RNA genes for phylogenetics. In: Innis, M.A., Gelfand, D.H., Sninksky, J.J. and White, T.J. (Eds), PCR Protocols: A Guide to Method and Amplifications. Academic Press, San Diego, California, pp. 315-322.

(Manuscript received on 22 March 2015; revised on 29 April 2015) 